\title{
The Forms of Political Participation in General Elections by Beginner
}

\section{Voters}

\author{
Aulia Sholichah Iman Nurchotimah \\ Informatics Engineering Study Program, Faculty of Informatics \\ Telkom Institute of Technology, Purwokerto, DI Panjaitan street No.128 Purwokerto Central Java, \\ Indonesia \\ aulia@ittelkom-pwt.ac.id
}

\begin{abstract}
Democracy as a government system in Indonesia is certainly closely related to the General Election. Participating in the implementation of a democratic system is a form of participation as citizens. Any activity that relates to participation in politics can be manifested in various forms. A beginner voter is a person who firstly participates in general election activities whether it is in the legislative election, presidential election, and local leader elections. Beginner voters become parties that must be considered or must be really paid attention to because they influence decision making. Beginners voters are also parties who have dynamic personal characteristics, which will influence their forms of political participation. The purpose of this study was to explore forms of political participation of beginner voters in general elections. Researcher used a qualitative approach and descriptive qualitative as the data analysis technique. The data which were used in this research were primary and secondary data. Data collection techniques were observation, interviews, and documentation. The results showed that the forms of political participation of beginner voters in the general election were voting, joinning campaign activities, participating in political discussion, understanding various political and social issues by following political news both internally and externally through the mass media, obeying the government, accepting, and implementing government decisions, submitting criticisms, and making improvements to rectify policies.
\end{abstract}

Keywords: Political Participation; General Election, Beginner Voter

\begin{abstract}
Abstrak. Demokrasi sebagai sistem pemerintahan di Indonesia tentunya sangat berkaitan dengan Pemilihan Umum. Ikut serta dalam pelaksanaan sistem demokrasi adalah wujud dari partisipasi sebagai warga negara. Suatu kegiatan berpartisipasi dalam politik, dapat diwujudkan dengan berbagai bentuk. Pemilih pemula merupakan seseorang yang pertamakali mengikuti kegiatan berbagai bentuk partisipasi politik pemilihan umum yang dilakukan diantaranya mengikuti pemilihan umum legislatif ataupun pemilihan pemimpin rakyat baik Presiden dan Wakil Presiden maupun Gubernur atau Bupati. Pemilih pemula menjadi pihak yang harus diperhatikan karena berpengaruh dalam pengambilan keputusan. Pemilih pemula juga merupakan pihak yang memiliki karakterisitik pribadi yang dinamis, yang akan mempengaruhi dari bentuk-bentuk partisipasi politiknya. Penelitian bertujuan untuk mengetahui lebih dalam terkait berbagai bentuk kegiatan partisipasi politik yang dilakukan oleh pemilih pemula dalam suatu kegiatan pemilihan secara umum. Penelitian ini menggunakan pendekatan kualitatif. Sumber data dalam penelitian ini mengambil sumber sekunder dan primer. Metode dalam mengumpulkan data diantaranya melakukan wawancara, kemudian observasi serta dokumentasi. Berbagai bentuk partisipasi dalam politik yang dilakukan oleh pemilih pemula dalam pemilihan umum yaitu mengikuti pemungutan suara, ikut serta dalam suatu kampanye politik dalam pemilihan umum, melakukan suatu diskusi mengenai politik dalam pemilihan umum, mengikuti berbagai berita politik dan pemilihan umum melalui media massa, patuh dalam rangka menjalankan aturan dari pemerintah serta ikut serta dalam upaya mengkritik pemerintah demi kebaikan bersama.
\end{abstract}

Kata Kunci: Partisipasi dalam Politik;Pemilihan Umum; Pemilih Pemula 


\section{INTRODUCTION}

Democracy as an electoral system in Indonesia is certainly closely related to the General Election. Participating in a democratic system is a form of participation as citizens. For a people's sovereignty that must be fought for. The general election held makes the people who play an important role and as a determinant in important decisions the results of the general election. People who in general elections become voters certainly have a big influence on elections, this also happens to voters who are first involved in election activities in an election that participates in political activity. Participation as a citizen is important in a democratic system. Participation in political activities is an effort of a citizen in a country as someone who is used to participating in influencing all who become the final result of the general election. This can affect the young generation in the future, which is related to his life. One can participate even in the simplest form of coming to a polling place and then voting to elect a leader. Then the participation activities in politics that can be followed by a voter that can be said to be beginners is to do active participation and passive participation (Surbakti, 2007)

Most participatory citizen systems, emphasizing the participation of citizens as the main thing, this idea is seen to be the most appropriate one because political representatives who are representatives of citizens or the people are considered not always to produce the best solution or decision. Therefore citizens must have more votes in elections. Because with the voice of the people will produce the best decisions for the people, because the people who know best what the needs and desires of the people themselves. (Gherghina \& Geissel, 2017)

A beginner voter is a person who first participates in activities in politics specifically organized in connection with the election of prospective leaders of a general nature, which is carried out both in the election of leaders at the national and regional levels. Beginner voters are an important part of the general election, Begginer Votersplay a role not only as a party affected in elections or just being an object but also having a role that can be called a political subject. The political participation of Begginer Votersis very important, participation in political activities can be explained various forms of activities that can be carried out in a series of phenomena in the election-related to the political process that can affect a country's policy (Budiardjo, 2008)

One of the most prominent forms of political participation is in elections, both to vote in general elections or to be elected in general elections, then participate in political decision making both large and simple decisions, then participate to influence decision making enter in an activity that can be categorized as participating in politics, political decisions if analyzed can have a social 
impact or impact on the wider community. Political participation has different levels, from the lowest to elect in elections and the highest is to have an official political office. (Shamsaei, 2016)

Various types of participation in politics can be done such as participating in election activities which are included in participating in the voting process, then following the campaign in the general election, and doing work in the election process, and can also be done by gathering support for someone in the election process general, next is lobbying, which is the efforts of a person or group to be able to make a communication with someone who has authority in the government or someone who leads the party so that they can participate in the political process that affects their influence in a decision taken (Huntington \& Nelson, 1994)

The form of participating in politics in the form of political discussion is not explained by Huntington and Nelson. It can be explained that a political chat which is called a discussion in politics is a process of discussion that is carried out directly, can be carried out in a certain time, this discussion can be carried out between individuals or in a group about political or prospective leaders and the government as the party making decisions for the people (Setiadi \& Usman, 2013) Voting in a general election is a political activity that can be categorized most broadly, through direct elections so that the people become a decisive party through the opportunity to elect leaders directly, in order to choose according to the criteria of the leader they want, how the leader will be chosen in general elections and be able to dominate and represent their interests, and to account for their choice. Many countries have experienced a decline in political participation in the long run, some have experienced the lowest levels of political participation in history. To overcome the fear of lack of legitimacy in democracy and the potential for biased policies due to the low level of political participation some countries have even considered implementing a mandatory system of voting for their citizens, therefore participating in voting is the most important part of democracy and political activity which is even considered to be required in some countries. (Einiö, 2014).

The participation of the younger generation includes voters being very important, everyone has the right to vote in elections, including the younger generation, participation is very important because it contributes to the process of policy formulation, political participation of the younger generation also in order to represent the aspirations of the generation young people and the interests of the younger generation. In political participation, the younger generation uses mass media such as watching the news on television and reading newspapers about politics. This is included in the political education of the younger generation. Political 
knowledge obtained from the media is a form of political participation, by forming selforientation in the political field in the surrounding environment (Etnel, 2010)

The younger generation, including newbie voters, are still interested in politics, one of which is a political discussion or engaging in politically oriented activities. Political socialization which is packaged into political education can be given to students as Begginer Votersto foster involvement in politics to stimulate greater political participation in the future. Political socialization as political education must be held by the government as an effort to foster the knowledge and experience of political participation of novice voters. (Jakobson \& Kalev, 2013)

Participation activities in general elections can certainly be seen based on a large number of participating actors. This can be categorized into participation in the individual form and also in the collective form. It can be explained that participation by individuals or individuals can be done for example by making a letter in the form of a complaint or claiming to the government, then it can also be done in a collective form, it can be in the form of political activities carried out jointly by citizens (Sahid, 2011).

Beginner voters become parties that must be considered because it influences decision making. Begginer Votersare also parties who have dynamic personal characteristics, which will influence the forms of political participation. Various activities that can be done by a novice voter are very important to be explored through a variety of activities that can be categorized as participation in politics, this is the goal of this research.

\section{RESEARCH METHODS}

In research on the forms of political participation in general elections by Beginner Voters, a descriptive qualitative approach was used. The data was taken from primary sources, namely the Commissioner of Banyumas Regency, Beginner Election in Banyumas Regency, Voting Committee in Banyumas Regency, and Election Supervisory Committee in Banyumas Regency, primary data sources were sources of information that provided information directly to researchers regarding the form of political participation in Banyumas. Conducted by beginner voters. Then the secondary data source that was as an indirect source that provided information and images to researchers (Sugiyono, 2009) by using interviews, in this study in-depth interviews (In Dept. Interview, and using Snow Ball Sampling in determining research informants. repeated meetings with informants in an effort to obtain data in order to obtain an essential source of evidence observation, in this study conducted by means of observation and even researchers participated in sharing the forms of political participation of Beginner 
Voters in Banyumas Regency, as well as documentation. This was to obtain data on forms of political participation carried out by beginner voters, in the form of photo documentation of political participation activities and also attendance lists in the implementation of political participation of Beginner Voters and minutes of political participation activities carried out by Beginner voters. This study took a location in the Regency of Banyumas with Banyumas Regency KPU informants and Beginner Voters in Banyumas Regency

\section{DISCUSSION}

General Elections as an embodiment of democracy was very important because this is where the people can determine the dreamer. The people are the parties who know best what they need, therefore in the general election system in Indonesia which is conducted directly by the people it is considered the most important of what is needed, Gherghina \& Geissel, 2017) they are needed, for that the government system and people's representatives are the interpretation of the people needed to protect the people. For this reason, people's participation in the form of political participation is very important in a democratic system.

As stated by (Pfanzelt \& Spies, 2019) that political participation is an act that is done voluntarily and can participate in elections, participate in political discussions that can be done with parents or family, and participate for use is also a form of participation political. Then the elaboration of (Shamsaei, 2016) said that political participation from the people is the main and important thing in a democratic country because people's representation is considered to be inadequate in making decisions that are in accordance with the needs of the people, so the people must participate in every political matter directly.

Beginner Voters become part of the party that determines the decision in the general election as stated by (Budiardjo, 2008) that political participation is very important to determine the direction of policy, as well as Beginner Voters in political activities to address their existence. According to the results of research that there is a variety of political participation in general elections conducted by Beginner Voters in Banyumas Regency in general elections, Various political participation in general elections by first-time voters is the first vote, according to (Huntington \& Nelson, 1994) that activities in participating in politics can be done in various ways, the first category can be done in an election activity, one of which chooses in general election. The second is in campaign activities, in campaigns can also be categorized into a form of political participation. A form of participation in voting in a general election will greatly influence the decisions or results of the general election, as well as a series of campaigns carried out by 
prospective candidates which will certainly influence a political orientation or even affect the political choices of voters. Voters in their participation in the campaign in order to find out information about the vision and mission of prospective leaders. As citizens who do not have the authority as public officials, this activity can be categorized as a participatory activity. Another element is the element of peace that must exist. Beginner Votersin Banyumas Regency carry out political participation peacefully and without anarchism.

This is in line with the opinion of (Einiö, 2014) that the form of political participation in elections is the broadest form of citizen involvement, for that beginner voters do the most general form of participation, namely voting in elections. Because if citizens do not directly vote for the dreamer or apathetic voter voters who cause low levels of voter turnout participation, it can lead to legitimacy from the results of general elections and bias, for this form of political participation is very important.

According to (Huntington \& Nelson, 1994) that there are activities in politics that fall into the category of classical participation. This classic participation is centered on the government, the people just follow the rules of the government. Starting from obeying what happens to government rules, by accepting a government policy and regulation and proceed with implementation as a consequence of the acceptance. Even more, there is an activity to criticize every policy made by the government aimed at improving and conforming to the needs of the people. This is an effort if the government takes a policy that is less appropriate for the interests of the people or even wrong. The society can participate to criticize and rectify it.

Political discussion is a part of political participation by novice voters. There is a classification from (Setiadi \& Usman, 2013) regarding political discussions that are classified as part of political activities that can be carried out by voters. Political discussion is a two-way process that promotes communication in it, the discussion can be done in person or through the media. In accordance with the opinion of (Susanto, 2017) that in the era of digital development, communication and information make social interaction easier, both between individuals and between groups. Social media is used as an information media which is chosen as one of them to find out information about politics.

Various forms of participation in politics carried out by first-time voters in general elections, namely following a vote, participating in a political campaign in general elections, conducting a discussion about politics in general elections, following various political news and general elections through the mass media, complying with an order to run the rules of the government and participate 
in efforts to criticize the government for a good for the all society.

Political discussion can be conducted between individuals who already know each other as friends or conducted by individuals who don't have the authority to be called ordinary citizens. The contents of the discussion will be in the form of discussions about politics. Beginner Voters in Banyumas Regency conduct political discussion even though the discussion is only with peers or with family or work colleagues, by talking lightly about the general election. Political discussion is also one of the results of political socialization, political socialization can be carried out early even in the smallest environment namely the family, in accordance with the opinion of (Neundorf, Smets, \& Holloway, 2016) that political socialization can be carried out by parents in the family sphere, then from school and from peers, in political socialization can produce a political discussion which is one form of political participation.

The results of this study are in accordance with the theory (Jakobson \& Kalev, 2013) that the younger generation including Beginner Voters are still interested in politics, one of which is a political discussion or engaging in politically oriented activities. Political discussion conducted by beginner voters takes the form of discussing funding political issues lightly with friends, family or in a more formal forum through political socialization packed into education about politics, delivered by schools or by authorized institutions or political parties that aim to provide knowledge about funding politics and increase political participation. Beginner voters in Banyumas Regency are many of them as a student, political discussion through political socialization or political education is given to students as Beginner Voters to foster involvement in politics so as to stimulate greater political participation in the future. Political discussion conducted by voters at the general election is about the candidate for the leader and the program offered by the candidate in order to prosper the people

Formally discussion activities regarding politics as well as political education in Banyumas Regency even to remote villages. Talks between peers, between family members, political discussions at work or elsewhere about politics are included in the activities of participation in informal political discussions. Informal discussion is often seen as a participatory activity that is easy and can be carried out by young people, but there are young people as voters who have just had the experience of choosing not to talk about political funding.

Various forms of political participation can be done by beginner voters, according to him (Surbakti, 2007), according to him, the activity of participating in politics can be seen from two categories, active and passive. It can 
be explained that what is meant actively is the people actively proposing ideas, ideas, and proposals regarding policies issued by the government. Not only that the people can also provide alternatives in policies issued by the government, even though the policies will be different from those made by the government. What included is in criticizing government policies which aim to improve government policies or to rectify those that are not appropriate in a policy. Participating in the process of selecting government leaders is also included in active participation.

Passive participation activities can also be carried out, including by complying with policies made by the government. The category of activities included in passive participation is to obey the rules of the government, carry out and support government policies If seen from active and passive participation, it can be explained that active participation in the whole process of political activities that prioritize the process of both the input process and the output process. Passive participation focuses only on the output of the political process. From this statement, it can be seen that if there are people who are not active participants and also passive participants, they are included in the white group or usually called abstain.

In Banyumas Regency, Beginner Voters participate in the form of coming to the polling station (polling station) to vote, and also submit a critique and suggestion for improving government policy. The results of the study indicate that there is a form of political participation of novice voters, namely in seeking information from the mass media regarding political developments, especially elections or watching political news in the mass media. This is consistent with the opinions of (Etnel, 2010) regarding one form of political participation of Beginner Voters by using mass media such as watching news on television and reading newspapers about politics. Because mass media such as television and newspapers as well as social media are digital developments that are familiar with the younger generation, the use of this media is also carried out by Beginner Voters in finding out information about politics, or even inadvertently obtaining information about politics broadcast in the mass media. Information can be in the form of a prospective candidate's vision and mission, and various information regarding the general election, this is important given that although there are novice voters, there are rational Beginner Voters who make information such as the candidates' vision and mission affect the criteria for the selection of new voters and that is obtained from the information in the mass media is in line with the results of research from (Abdullah, 2019) that students who are mostly also beginner or rational young voters have their criteria for leaders who are adjusted from the vision and mission of the candidate. 
Mass media that can be used properly can become a medium for political education in the younger generation. Political knowledge obtained from the media is a form of political participation, by forming self-orientation in the political field in the surrounding environment, this is in accordance with what was stated by (Adnan, Wildan Kurniawan, Raturahmi, \& Latifah, 2020) that social media or mass media chosen as a means of socialization Election by the election organizer or by a candidate pair to attract the attention of Beginner Voters because Beginner Voters as first-time voters tend to like short and interesting messages. This can be understood by the majority of beginner voters who do have a young soul prefer things light and easy to understand, but there is information that can be known by novice voters.

\section{CONCLUSION}

Political participation by citizens is very important in a democratic country. Beginner Voters are citizens who also have voting rights. The political participation of Beginner Voters in the general election is very diverse. Various forms of participation in politics conducted by Beginner Voters in general elections, namely following a vote, participating in a political campaign in general elections, conducting a discussion about politics in general elections, following various political news and general elections through the mass media, complying with order to run the rules of the government and participate in efforts to criticize the government for good thing for the all societies.

\section{REFERENCES}

[1] Abdullah, M. (2019). Rational Political Behaviour on Young Generation Voter. International Journal Pedagogy of Social Studies, $\quad 4(1), \quad 64-70$. https://doi.org/10.17509/ijposs.v4i1.17961

[2] Adnan, I. Z., Wildan Kurniawan, A., Raturahmi, L., \& Latifah, H. (2020). Local Elections in the Social Media Era (Socialization of Local Election through Social Media for Beginner Voters by Garut Regency Election Commission in 2018 Regional Election). KnE Social Sciences, 2020, 113-121. https://doi.org/10.18502/kss.v4i4.6474

[3] Budiardjo, M. (2008). Dasar-Dasar Ilmu Politik. Jakarta: Gramedia Pustaka.

[4] Einiö, E. (2014). R\&D Subsidies and Company Performance: Evidence from Geographic Variation in Government Funding Based on the ERDF PopulationDensity Rule. Review of Economics and Statistics, $\quad$ 96(4), 710-728. https://doi.org/10.1162/REST

[5] Etnel, P. (2010). Young people and political participation: Defining the role of young people in politics. (April).

[6] Gherghina, S., \& Geissel, B. (2017). Linking Democratic Preferences and Political Participation: Evidence from Germany. Political Studies, 65(1_suppl), 24-42. https://doi.org/10.1177/0032321716672224

[7] Huntington, S. P., \& Nelson, J. (1994). Partisipasi Politik di Negara Berkembang (Terj.). Jakarta: Rineka Cipta.

[8] Jakobson, M. L., \& Kalev, L. (2013). Transnational citizenship as status, identity and participation: Comparative assessment. In Democracy in Transition: Political Participation in the European Union. https://doi.org/10.1007/978-3-642-300684_11 
[9] Neundorf, A., Smets, K., \& Holloway, R. (2016). Political Socialisation and the Making of Citizens Chapter for Oxford Handbook Online.

[10] Pfanzelt, H., \& Spies, D. C. (2019). The Gender Gap in Youth Political Participation: Evidence from Germany. Political Research Quarterly, 72(1), 34-48. https://doi.org/10.1177/1065912918775249

[11] Sahid, K. (2011). sosiologi politik. Bogor: Ghalia Indonesia.

[12] Shamsaei, M. (2016). Article Women' $S$ Political Participation, Obstacle And. 7, 435-440.

[13] Sugiyono. (2009). Metode Penelitian Kuantitatif, Kualitatif, dan $R \& D$. Bandung: Alfabeta.

[14] Surbakti, R. (2007). Memahami Ilmu Politik. Jakarta: Gramedia Widiasarana Indonesia.

[15] Susanto, E. H. (2017). Media Sosial Sebagai Pendukung Jaringan Komunikasi Politik. Jurnal Aspikom. https://doi.org/10.24329/aspikom.v3i3.123 